\title{
STUDI KEPUASAN PENGHUNI TERHADAP PROGRAM PEMERINTAH DALAM PEMBERDAYAAN MASYARAKAT RUSUNAWA (STUDI KASUS: RUSUNAWA JN BARAT)
}

\author{
Amos Amir Dohar' \\ ${ }^{1}$ Fakultas Teknik, Universitas Tarumanagara, Jakarta \\ Email : amospanjaitan.85@gmail.com
}

\begin{abstract}
ABSTRAK
Pelaksanaan Program Pemberdayaan Masyarakat pada Rusunawa JN Barat sebagai salah satu program pemerintah dalam membentuk hunian yang layak bagi warga yang terkena normalisasi sungai Ciliwung, yang diidentifikasi berdasarkan peraturan Gubernur terlihat bahwa terdapat capaian yang nyata dan sesuai dengan tujuan adanya program pemberdayaan masyarakat. Pencapaian ini juga diidentifikasi berdasarkan kuesioner yang telah di distribusikan kepada responden selaku penghuni di rusunawa JN Barat, dan beberapa pencapaian yang cukup terlihat adalah khususnya pada bidang bina ekonomi yaitu meningkatnya pendapatan masyarakat berpenghasilan rendah, tumbuh dan berkembangnya usaha mikro, dan juga terbangun dan berkembangnya potensi ekonomi masyarakat. Penelitian ini menggunakan metode kuantitatif deskriptif yang dilakukan dengan observasi lapangan, dan melakukan penyebaran kuesioner kepada responden yang jumlahnya sudah ditentukan. Pencapaian dari penelitian ini ditemukan bahwa adanya Penerapan Program Pemberdayaan Masyarakat yang sangat berpengaruh terhadap tingkat perekonomian masyarakat dan juga interaksi sosial masyarakat Rusunawa JN Barat.
\end{abstract}

Kata Kunci : Pemberdayaan, Masyarakat, Rusunawa, Kuantitatif, Kuesioner, Pencapaian

\section{PENDAHULUAN}

Pemerintah Daerah DKI Jakarta memiliki salah satu upaya untuk Mempercepat upaya peningkatan kesejahteraan masyarakat di Kelurahan dengan membuat suatu Keputusan Gubernur Provinsi Daerah Khusus Ibukota Jakarta Nomor 1747/2003 tentang Perubahan Lampiran Keputusan Gubernur Provinsi DKI Jakarta Nomor 1561/2002 tentang pedoman pelaksanaan program pemberdayaan masyarakat kelurahan (PPMK) dalam rangka mempercepat upaya peningkatan kesejahteraan masyarakat di Kelurahan Provinsi DKI Jakarta tahun $2003-2007$.

Terdapat beberapa permasalahan yang timbul pasca relokasi salah satunya adalah keberlangsungan hidup masyarakat yang tinggal di Rusunawa tersebut. Keberlangsungan hidup dalam hal ini mencakup mata pencaharian yang berubah, lapangan kerja yang tidak memungkinkan untuk di lanjutkan kembali sehingga menyebabkan pengangguran, lalu pengeluaran yang semakin bertambah karena penghuni diwajibkan untuk membayar sewa setiap bulan. Sehingga, terdapat beberapa program pemerintah untuk memberdayakan penghuni rusunawa tersebut seperti yang tercantum pada PERGUB 1747 tahun 2003 yang menyatakan bahwa PPMK (Program Pemberdayaan Masyarakat Kelurahan) dengan pendekatan Tri Bina (Bina Ekonomi, Bina Fisik Lingkungan dan Bina Sosial) dan PPMK memberikan peran untuk masyarakat untuk merencanakan, melaksanakan dan mengawasi. Selanjutnya tercantum pada PERGUB No 34 tahun 2007 menyatakan bahwa Bina Fisik Lingkungan dengan tujuan: (1) Terwujudnya sarana dan prasarana lingkungan berskala mikro yang memadai, (2) Terwujudnya kemandirian dan kepedulian masyarakat untuk memperbaiki dan menata lingkungannya, (3) Terwujudnya swadaya dan gotong royong masyarakat dalam penataan dan perbaikan lingkungan, sedangkan hal-hal yang termasuk dalam Bina sosial dengan tujuan: (1) Meningkatnya kemampuan daya saing anggota masyarakat, (2) Meningkatnya peran serta lembaga masyarakat dalam menghimpun dan mengembangkan kemampuan masyarakat, (3) 
Meningkatnya kesetiakawanan sosial, kepedulian sosial, dan kerja sama antar unsur masyarakat. Selain itu tujuan dalam adanya Bina Ekonomi adalah: (1) Meningkatnya pendapatan masyarakat berpenghasilan rendah, (2) Tumbuh dan berkembangnya usaha mikro, (3) Terbangun dan berkembangnya potensi ekonomi masyarakat.

Adanya penurunan kemampuan ekonomi bagi masyarakat yang tinggal di Rusunawa JN Barat. Sehingga, dalam hal ini pemerintah turut serta untuk meningkatkan kemampuan ekonomi masyarakat yang juga merupakan salah satu dari tujuan adanya Program Pemberdayaan Masyarakat. Dalam penelitian ini juga akan melihat secara menyeluruh penerapan program pemberdayaan masyarakat di Rusunawa JN Barat.

Berdasarkan fenomena dan permasalahan yang terjadi mendorong dilakukannya penelitian ini yang diarahkan untuk menjawab pertanyaan: Bagaimana tingkat kepuasan penghuni Rusunawa terhadap penerapan program pemberdayaan masyarakat di Rusunawa JN Barat?

\section{METODE PENELITAN}

Program relokasi atau resettlement merupakan program yang dilaksanakan dengan perencanaan yang sangat cermat. Bank Dunia (1999) merekomendasikan bahwa sebelum memutuskan rencana relokasi perlu mempersiapkan kerangka rencana atau kerangka kebijakan permukiamn kembali secara matang. Program relokasi dikembangkan atas dasar partisipatif, sehingga keputusan pemukiman kembali dibuat sendiri oleh masyarakat.

Dampak sosial adalah perubahan dalam kondisi kehidupan orang- orang yang terjadi bersama dengan suatu kebijakan yang baru, program atau proyek. Problem inti dari relokasi adalah kehilangan masyarakat atas mata pencaharian serta penurunan kemampuan potensial mereka akibat dari pemindahan tersebut. Ketika suatu komunitas terpaksa untuk pindah maka system produksi yang sudah ada menjadi berkurang. Banyak pekerjaan, lahan yang bernilai, serta asset pendapatan yang hilang. Kelompok kekerabatan serta jaringan sosial informal yang tercerai berai. Resiko yang paling sering dihadapi oleh penduduk bantaran sungai yang permukimannya harus dipindahkan adalah kehilangan lahan, kehilangan pekerjaan, kehilangan hunian, kehilangan terhadap akses produksi dan disartikulasi komunikasi.

Pemberdayaan masyarakat sendiri memiliki makna yang telah disampaikan oleh Prijono dan Pranarka (1996, h. 77) yaitu pemberdayaan mengandung dua arti, pengertian pertama adalah to give power or authority, pengertian kedua to give ability to or enable. Pemaknaan pengertian pertama meliputi memberikan kekuasaan, mengalihkan kekuatan atau mendelegasikan otoritas kepada pihak yang kurang/belum berdaya. Di sisi lain pemaknaan pengertian kedua adalah memberikan kemampuan atau keberdayaan serta memberikan peluang kepada pihak lain untuk melakukan sesuatu.

Metode yang digunakan dalam penelitian ini adalah metode kuantitatif deskriptif memusatkan perhatian pada masalah-masalah atau fenomena-fenomena yang ada pada saat penelitian atau masalah yang bersifat actual, kemudian menggunakan fakta-fakta tentang masalah yang diteliti diiringi dengan interpretasi rasional akurat. Pada metode deskriptif peneliti menyajikan datadata penelitian dan menganalisis temuan-temuan yang ada serta memberikan tinjauan kritis. 
Metode kualitatif dalam penelitian ini digunakan dalam analisis tertentu seperti pada analisis program pemberdayaan masyarakat. Dalam analisis tersebut mengharuskan peneliti mengerti dan memahami penerapan program pemberdayaan masyarakat di Rusunawa JN. Hal-hal yang sudah diterapkan maupun hal yang belum diterapkan, sehingga peneliti menggunakan metode kualitatif pada analisis tersebut.

\section{HASIL DAN DISKUSI}

Berdasarkan hasil kuesioner yang di distribusikan oleh responden yang tinggal di Rusunawa JN Barat, ditemukan beberapa perubahan dari sebelum dan sesudah di relokasi yaitu sebagai berikut; adanya kenaikan pada angka Penghuni yang tidak bekerja, dari 8,75\% menjadi 21,25\%. Selain itu, juga terdapat penurunan persentase pada jenis pekerjaan Karyawan Swasta dari $17,5 \%$ menjadi $10 \%$. Adanya penurunan dan kenaikan tersebut disebabkan karena berubahnya lokasi tempat tinggal, dimana terdapat beberapa warga yang pada awalnya memiliki warung atau toko lalu saat pindah ke Rusunawa tidak dapat melanjutkan usahanya tersebut.

Transportasi ke Tempat Kerja Sebelum dan Setelah Relokasi adanya penurunan persentase dengan Jalan Kaki dari 54\% dan 43\% sedangkan adanya peningkatan pada penggunaan moda Bus/Angkutan Kota dari $17 \%$ menjadi $28 \%$. Adanya perubahan tersebut juga dipengaruhi oleh berubahnya lapangan pekerjaan dan juga adanya perubahan lokasi tempat tinggal, selain itu Rusunawa JN Barat memiliki akses yang mudah dari dan menuju Bus Transjakarta maupun Angkutan Kota lainnya sehingga adanya peningkatan pada penggunaan moda Bus atau Angkutan Kota.

Lama Perjalanan ke Tempat Kerja Sebelum dan Setelah Relokasi adanya peningkatan pada < 30 menit dengan persentase sebesar $76 \%$ menjadi $80 \%$. Sedangkan pada $30-60$ menit terlihat adanya penurunan dari $21 \%$ menjadi $18 \%$. Hal tersebut dapat disebabkan karena adanya perubahan moda transportasi menjadi angkutan umum, sehingga penghuni rusunawa termotivasi untuk berangkat lebih awal dibandingkan dengan sebelumnya.

Biaya transportasi ke tempat kerja sebelum dan Setelah relokasi terdapat kenaikan pada Tanpa Biaya dengan persentase dari $52 \%$ menjadi $54 \%$ dan terjadi kenaikan biaya transportasi $<\mathrm{Rp}$ 7000 dari $12 \%$ menjadi $23 \%$. Hal tersebut dapat terjadi karena adanya perubahan pada moda transportasi yang digunakan untuk menuju ke tempat kerja dari kendaraan pribadi menjadi angkutan umum.

Penghasilan kepala keluarga sebelum dan Setelah relokasi terdapat kenaikan pada range penghasilan Rp. 3.000 .000 - Rp. 4.000 .0000 dari $24 \%$ dan 26\%. Dan adanya penurunan pada range penghasilan Rp. 2.000.000 - Rp. 3.000.000 dari 34\% menjadi 20\%. Penurunan penghasilan ini terkait dengan adanya perubahan pekerjaan para penghuni dan juga terdapat kenaikan pada kategori tidak bekerja di Rusunawa JN Barat.

Pengeluaran keluarga untuk Makan sebelum relokasi mayoritas mengeluarkan biaya sebesar Rp. 1.000.000 - Rp. 2.000.000,- dengan persentase sebesar 46\%, sedangkan setelah relokasi pengeluaran keluarga untuk makan mayoritas mengeluarkan biaya sebesar Rp. 1.000.000 - Rp. 2.000.000 dengan persentase sebesar 60\%. Terlihat pada kategori pengeluaran Rp. $2.000 .000-$ Rp. 3.000 .000 memiliki penurunan dari $23 \%$ saat sebelum relokasi menjadi $13 \%$ setelah relokasi. Asumsi dari adanya penurunan pengeluaran tersebut adalah adanya bantuan bahan pangan, sehingga beberapa aspek bahan pangan dapat dialokasikan ke bahan pangan lainnya. 
Pengeluaran keluarga untuk Air, Listrik, Service Charge sebelum relokasi mayoritas mengeluarkan biaya sebesar $<$ Rp 200.000 dengan persentase sebesar 77,5\%, sedangkan setelah relokasi pengeluaran keluarga untuk Air, Listrik, Service Charge mayoritas sebesar Rp 0 yaitu sebesar $67,5 \%$. Terjadi penurunan di pengeluaran $\mathrm{Rp}<200.000$ sebesar $61,2 \%$ dari 77,5\% menjadi $16,3 \%$ serta pada Rp 200.000 - Rp 400.000 dari 18,8\% menjadi 6,3\%. Hal tersebut diasumsikan karena harga sewa yang telah dibayar sudah termasuk dengan biaya air, listrik para penghuni.

Pengeluaran keluarga untuk Pendidikan sebelum relokasi dan Setelah relokasi memiliki persentase yang besar pada kategori Tidak Mengeluarkan Biaya. Hal ini merupakan salah satu program pemberdayaan masyarakat pada bidang pendidikan dengan penerapan KJP (Kartu Jakarta Pintar) untuk menanggung biaya pendidikan anak usia sekolah.

Perubahan kredit motor dari sebelum relokasi sebesar 11,25\% menjadi 2,5\% setelah relokasi; Pembelian barang lainnya menurun dari $30 \%$ menjadi $21,25 \%$, dan tidak ada kredit apapun meningkat dari 57,5\% menjadi 76,25\%. Hal ini disebabkan karena adanya beberapa barang yang sudah lunas dari sebelum tinggal di Rusunawa JN Barat.

Penurunan tingkat kredit di kategori < Rp 500.000 dari 28,75\% menjadi $18,75 \%$, penurunan di kategori Rp 500.000 - Rp 1.000.000 dari 13,75\% menjadi 7,5\%, dan ada peningkatan penduduk tanpa kredit dari $57,5 \%$ menjadi $73,75 \%$. Hal ini terkait dengan penurunan persentase pada barang yang dibeli secara kredit, sehingga pembayaran kredit per bulan juga menurun.

Rekapitulasi kondisi ekonomi masyarakat penghuni Rusunawa sebelum dan sesudah adanya Relokasi dapat dilihat pada tabel berikut:

Tabel 1. Rekapitulasi Kondisi Ekonomi Masyarakat Sebelum dan Setelah Relokasi

\begin{tabular}{|c|c|c|}
\hline Variabel & Sebelum Relokasi & Setelah Relokasi \\
\hline Penghasilan Keluarga & $\begin{array}{l}\text { Mayoritas }(43,2 \%) \text { memiliki } \\
\text { penghasilan Rp. } 1.000 .000 \text { - } \\
\text { Rp. } 3.000 .000\end{array}$ & $\begin{array}{l}\text { Mayoritas }(51,25 \%) \\
\text { memiliki penghasilan Rp. } \\
1.000 .000 \text { - Rp. } 3.000 .000\end{array}$ \\
\hline \multicolumn{3}{|c|}{ Pengeluaran Keluarga } \\
\hline a. Makan & $\begin{array}{l}\text { Mayoritas (46\%) memiliki } \\
\text { pengeluaran Rp. } 1.000 .000 \text { - } \\
\text { Rp. 2.000.000 }\end{array}$ & $\begin{array}{l}\text { Mayoritas }(60 \%) \text { memiliki } \\
\text { pengeluaran Rp. } \\
1.000 .0000 \text { - Rp. } 2.000 .000\end{array}$ \\
\hline $\begin{array}{l}\text { b. Pengeluaran Air, Listrik, dan } \\
\text { Service Charge }\end{array}$ & $\begin{array}{l}\text { Mayoritas }(77,5 \%) \text { memiliki } \\
\text { pengeluaran }<\text { Rp. } 200,000\end{array}$ & $\begin{array}{l}\text { Mayoritas }(67,5 \%) \text { tidak } \\
\text { mengeluarkan biaya }\end{array}$ \\
\hline c. Pendidikan & $\begin{array}{l}\text { Mayoritas }(67,5 \%) \text { tidak } \\
\text { mengeluarkan biaya }\end{array}$ & $\begin{array}{l}\text { Mayoritas }(67,5 \%) \text { tidak } \\
\text { mengeluarkan biaya }\end{array}$ \\
\hline Pembayaran kredit & Mayoritas (57\%) tidak ada. & Mayoritas $(74 \%)$ tidak ada. \\
\hline Status Kepemilikan Rumah & $\begin{array}{l}\text { Mayoritas }(84 \%) \text { rumah } \\
\text { sendiri. }\end{array}$ & Mayoritas (99\%) sewa. \\
\hline Jangka waktu tinggal & Mayoritas $(86 \%)>20$ Tahun. & $\begin{array}{l}\text { Mayoritas (98\%) 1-2 } \\
\text { Tahun. }\end{array}$ \\
\hline
\end{tabular}

Sumber : Hasil Kuesioner, 2017 


\section{KESIMPULAN DAN SARAN}

Setelah dilakukannya keterkaitan antara penghasilan keluarga dan kepuasan dalam bidang ekonomi didapatkan bahwa hanya beberapa lapisan masyarakat yang merasa puas pada program pemberdayaan masyarakat pada bidang ekonomi, khususnya masyarakat yang memiliki penghasilan > Rp. 3.000.000. Belum meratanya penghasilan masyarakat atau kondisi ekonomi masyarakat juga dipengaruhi karena perbedaan latar belakang pendidikan dan tingkat kemampuan masing-masing masyarakat.

Pada umumnya sudah puas terhadap program pemberdayaan masyarakat terkait dengan sasaran yang telah dilakukan oleh pemerintah. Dimana terlihat bahwa PPM yang tertinggi tingkat kepuasannya ada pada indikator bidang fisik dan lingkungan perumahan; dikarenakan oleh adanya relokasi ke tempat tinggal yang lebih baik. Selain itu, beberapa indikator masih tergolong kurang optimal yaitu pada sisi tenaga kerja, hal ini dikarenakan adanya pergantian mata pencaharian warga serta penghasilan yang belum sesuai harapan para penghuni sehingga mereka merasa kurang puas.

Dari deskripsi kesimpulan tersebut bila dikaitkan dengan tinjauan pustaka yang digunakan dalam penelitian ini diperoleh bahwa adanya perbaikan kondisi perumahan dan infrastruktur publik yang disediakan pemerintah bagi penghuni Rusunawa JN sudah sesuai dengan teori relokasi yang dipaparkan. Selain itu pada teori pemberdayaan masyarakat Rusunawa JN Barat belum sepenuhnya membuat masyarakat menjadi mandiri dan belum sepenuhnya dihasilkan atas usaha masyarakat, hal ini disebabkan masih adanya masyarakat yang belum berpartisipasi dalam program pemberdayaan masyarakat ini. Selain itu, masih ada masyarakat yang kurang setuju dengan relokasi dan menganggap bahwa relokasi merupakan salah satu hal yang kurang disukai. Sehingga, hal ini masih sangat bergantung pada pendekatan masyarakat yang dilakukan oleh pemerintah.

\section{Ucapan Terima Kasih}

Penulis menyampaikan terima kasih atas partisipasi dan dukungan dari para partisipan dalam penelitian ini.

\section{REFERENSI}

Bryan, C. (1987). Manajemen Pembangunan Untuk Negara Berkembang. LP3ES: Jakarta.

Chatanese, A. J \& Snyder, J. C. (1996). Perencanaan Kota. Jakarta:Erlangga.

Engel, J.F., Backwell, R. D., \& Miniard, P.W. (1995). Perilaku Konsumen Jilid II. Alih Bahasa Budiono FX. Jakarta: Binarupa Aksara.

Harinaldi (2005) Prinsip-Prinsip Statistik Untuk Teknik dan Sains, Jakarta: Erlangga.

Harri A. S. (2015) Analisis Faktor Berpengaruh Terhadap Kepuasan Penghuni Rumah Susun Sewa Studi Kasus Rumah Susun Sewa Kemayoran. Jurnal Permukiman, Pusat Litbang Permukiman, Badan Litbang Kementerian Pekerjaan Umum.

Keputusan Gubernur Propinsi DKI Jakarta Nomor 1747/2003 tentang Perubahan Lampiran Keputusan Gubernur Propinsi DKI Jakarta Nomor 1561/2002 tentang Pedoman Pelaksaaan Program Pemberdayaan Masyarakat Kelurahan (PPMK) dalam Rangka Mempercepat Upaya Peningkatan Kesejahteraan Masyarakat di Kelurahan Propinsi DKI Jakarta Tahun 2003 - 2007.

Mardi Y. H. (2000) Pemberdayaan Masyarakat dalam Bidang Ekonomi: Tinjauan Teoritik dan Implementasi. Yogyakarta: Universitas Wangsamanggala Yogyakarta.

Mowen, J. C (1995) Consumer Behavior. New York: Prentice-Hall International.

Peraturan Gubernur Provinsi DKI Jakarta Nomor 34 Tahun 2007 tentang Petunjuk Pelaksanaan Program Pemberdayaan Masyarakat Kelurahan Provinsi DKI Jakarta 
Peraturan Gubernur Provinsi DKI Jakarta Nomor 53 Tahun 2007 tentang Arah, Kebijakan dan Strategi Penanggulangan Kemiskinan.

Sandjaya, T. (2003) Analisa Pengaruh Kualitas Produk Terhadap Kepuasan Konsumen Dalam Membeli Rumah di Rumah Susun Menanggal Surabaya. Skripsi tidak diterbitkan. Surabaya : Fakultas Teknik Sipil dan Perencanaan Institut Teknologi Adhi Tama Surabaya.

Sastra M, Suparno \& Marlina, E. (2006) Perencanaan dan Pengembangan Perumahan.Yogyakarta: Andi.

Sugiyono (2008). Metode Penelitian Kuantitatif, Kualitatid dan R\&D. Bandung: Penerbit Alfabeta.

Suliyanto (2005) Analisis Data Dalam Aplikasi Pemasaran. Bogor : Ghalia Indonesia.

Tjiptono, F. (1997) Strategi Pemasaran. Yogyakarta: Andi Offset. Edisi I dan II.

Veronica, C. \& Supani (2009). Analisa Kepuasan Penghuni Perumahan Pondok Tjandra Indah Berdasarkan Faktor Lokasi, Harga, Prasarana dan sarana. Prosiding Seminar Naional Teknik Sipil , 11 Februari 2009, Ruang Sidang Jurusan Teknik Sipil FTSP, Institut Teknologi Sepuluh Nopember Surabaya.

Wicaksono, A. A (2005). Mengelola Investasi Real Estat. Semarang: Trubus Agriwidia.

Winarno, J. (2005) Studi Kepuasan Konsumen Terhadap Rumah Tinggal Tipe 36 di Wilayah Kabupaten Kediri. Skripsi tidak diterbitkan. Surabaya: Fakultas Teknik Sipil dan Perencanaan Institut Teknologi Adhi Tama Surabaya 